\title{
The Influence of Altitude and Latitude on Breeding of Amomum tsaoko (Zingiberaceae)
}

\author{
Yao-Wen Yang1,2, Xiao-Li Liu1 ${ }^{1}$, Chun-Xia Pu1,2, Zi-Gang Qian ${ }^{{ }^{*}}$, Kai-Yun Guan² ${ }^{2 *}$ \\ ${ }^{1}$ The Center for Reproducing Fine Varieties of Chinese Medicinal Plants, Yunnan College of TCM, Kunming, \\ China \\ ${ }^{2}$ Kunming Institute of Botany, Chinese Academy of Sciences, Kunming, China \\ Email: "'gianzig@126.com, ${ }^{*}$ guanky@mail.kib.ac.cn
}

Received December 2013

\begin{abstract}
Objective: To explore the effect of altitude and latitude on breeding of Amomum tsaoko Crevost et Lemaire, a flexistylous ginger, which fruit is used as common materia medica and a food condiment. Methods: The 7 populations were selected randomly from the three floristic zones of Yunnan. Adult plants and infructescences were chosen randomly to gain flower number and fructification percentage per inflorescence, and seed number per fruit. All date was analyzed by SPSS (13.0 version). Results: As A. tsaoko was distributed (or transplanted) from a habitat at lower latitude and/or altitude to a site of higher latitude and/or altitude, the flower number per inflorescence increased, on the contrary, the fructification percentage per inflorescence decreased. The competition for reproductive resource was beneficial to increase flower number and seed production. Conclusions: The habitats in south of the tropic of cancer were favorable to the reproduction of $A$. tsaoko, which reproductive costs were lower and harvest was higher. Increasing flower number per inflorescence may be a strategy to promote the plant to distribute into alpine habitats for both female and male reproductive success.
\end{abstract}

\section{Keywords}

Amomum tsaoko; Flower Number per Inflorescence; Reproduction; Trade-Off; Floral Longevity

\section{Introduction}

Amomum tsaoko Crevost et Lemaire is a flexistylous ginger cultivated in China for collection fruit as common materia medica [1] and a food condiment. The plant distributed in Yunnan province, Southwest China [2], but now its wild (or natural) population is almost extinct in Yunnan, and it is cultivated as an economic plant at many areas in the province.

In the course of cultivation of the plant, how did environmental factors influence on its reproduction? And

${ }^{*}$ Corresponding authors.

How to cite this paper: Yang, Y.-W., Liu, X.-L., Pu, C.-X., Qian, Z.-G. and Guan, K.-Y. (2014) The Influence of Altitude and Latitude on Breeding of Amomum tsaoko (Zingiberaceae). Journal of Biosciences and Medicines, 2, 9-17.

http://dx.doi.org/10.4236/jbm.2014.21002 
how did the plant adapt to the environmental changes? Because flower, fruit and seed are reproductive organs of plant, so their quantitative change would reflect the reproduction conditions of a population, and reproductive resource status of the plant [3-6]. Therefore, we studied the reproduction conditions of the 7 populations of $A$. tsaoko in different areas, and address the following questions: 1) how did latitude and altitude influence on the flower number and fructification percentage per inflorescence, seed number per fruit? 2) How is the reproductive competition among the flower number and fructification percentage per inflorescence, seed number per fruit? 3) How does the flowering strategy of the plant change to adapt to alpine habitats? 4) How is the site chosen for cultivation of the plant?

\section{Material and Method}

\subsection{Research Species}

A. tsaoko is a perennial herb of Zingiberaceae, usually 2 - $3 \mathrm{~m}$ in height. Inflorescence consists of a densely flowered spike that arises from rhizomes. Distinct characters of the plant from the other Amomum species are a showy yellow labellum with two red nectar guides, anther appendage, crimson and leathery ligule. Flowering occurs from April to June, and by September-December capsules are ripe [2].

\subsection{Study Sites and Field Observation}

Yunnan province was broken into five floristic zones [7]. Our preliminary investigation showed that A. tsaoko was growing in the three floristic zones: 1) the south and southwest, 2) the southeast, 3) the west and northwest. In each floristic zone, 2 or 3 populations were chosen to test the effect of altitude and latitude on breeding of the plant (Table 1). In each population, we selected adult plants at random, and ripe infructescences were sampled randomly from each individual in August-October. These infructescences were subjected to observations. We got both the number of mature fruits (excluding immature ones which maybe fell off early after anthesis) and scars of flowers in an infructescence (i.e. the number of flowers in a ripe inflorescence), and also got number of seeds in each fruit.

\subsection{Statistical Analyses}

Per infructescence, fructification percentage was the proportion of mature fruit number to total flower number. Date on fructification percentage, flower number per inflorescence and seed number per fruit, as well as altitude and latitude of the 7 populations were checked by Homogeneity of variance test, and compared by one-way analysis of variance (ANOVA) test. Student Newman Keuls Test (S-N-K test) was used for multiple comparisons among pairs of means. Correlation was tested by Partial Correlate and Stepwise. For statistical tests, the SPSS statistical program package (13.0 version) was used.

\section{Results}

\subsection{Comparison of Flower Number and Fructification Percentage per Inflorescence, Seed Number per Fruit among the 7 Populations}

Flower number per inflorescence was $87.49 \pm 21.25$ (Mean \pm SD, range from 9 to 143), and fructification percentage per inflorescence was $19.06 \pm 11.07$ (range from 1.57 to 54.93) \% (Table 2). For flower number and fructification percentage per inflorescence, greatly significant differences were detected among the 7 populations and among the plant individuals (Table 3 ).

Seed number per fruit was $33.03 \pm 12.63$ (range from 1 to 82) (Table 4), with greatly significant difference among the populations $(d f=6, F=6.945, P=0.000<0.01=$ and the plant individuals $(d f=94, F=33.839, P=$ $0.000<0.01$ ). By S-N-K test of seed number per fruit, the 7 populations were divided into 4 subsets (Table 5).

\subsection{The Influences of Altitude and Latitude on Flower Number and Fructification Percentage per Inflorescence, Seed Number per Fruit}

By controlling the influence of populations, significant negative correlation was detected between flower num- 
Table 1. Information of the seven populations of A. tsaoko.

\begin{tabular}{|c|c|c|c|c|c|c|c|c|}
\hline Population & Site & Altitude (m) & Latitude & Floristic zones* & Geographical location $^{* *}$ & Individual & Inflorescence & Fruit \\
\hline 1 & Maguan & 1524 & $22^{\circ} 51.631^{\prime} \mathrm{N}$ & 2 & S & 16 & 76 & 934 \\
\hline 2 & Lvchun & 2043 & $22^{\circ} 53.837^{\prime} \mathrm{N}$ & 1 & S & 18 & 81 & 1587 \\
\hline 3 & Baoshan & 2070 & $24^{\circ} 50.289^{\prime} \mathrm{N}$ & 3 & $\mathrm{~N}$ & 15 & 68 & 1203 \\
\hline 4 & Jinping & 1662 & $22^{\circ} 51.783^{\prime} \mathrm{N}$ & 2 & S & 14 & 57 & 1021 \\
\hline 5 & Jinghong & 1581 & $21^{\circ} 29.675^{\prime} \mathrm{N}$ & 1 & S & 14 & 54 & 925 \\
\hline 6 & Xichou & 1670 & $23^{\circ} 22.326^{\prime} \mathrm{N}$ & 2 & S & 14 & 56 & 906 \\
\hline 7 & Gongshan & 1425 & $27^{\circ} 32.952^{\prime} \mathrm{N}$ & 3 & $\mathrm{~N}$ & 10 & 42 & 702 \\
\hline & & & Total & & & 101 & 434 & 7278 \\
\hline
\end{tabular}

" 1 : the south and southwest, 2: the southeast, 3 : the west and northwest; ${ }^{* *} \mathrm{~S}$ : South of the tropic of cancer $\left(23^{\circ} 26^{\prime} \mathrm{N}\right), \mathrm{N}$ : North of the tropic cancer.

Table 2. Descriptives of the inflorescences from the seven populations.

\begin{tabular}{|c|c|c|c|c|c|c|c|c|c|}
\hline \multirow{2}{*}{ Character } & \multirow{2}{*}{ Population } & \multirow{2}{*}{$\mathrm{N}$} & \multirow{2}{*}{ Mean } & \multirow{2}{*}{$\begin{array}{c}\text { Std. } \\
\text { Deviation }\end{array}$} & \multirow{2}{*}{ Std. Error } & \multicolumn{2}{|c|}{ 95\% Confidence Interval for Mean } & \multirow{2}{*}{ Minimum } & \multirow{2}{*}{ Maximum } \\
\hline & & & & & & Lower Bound & Upper Bound & & \\
\hline \multirow{8}{*}{$\begin{array}{c}\text { Flower } \\
\text { number per } \\
\text { inflorescence }\end{array}$} & 1 & 76 & 78.7765 & 20.4062 & 2.2134 & 74.3750 & 83.1780 & 25 & 127 \\
\hline & 2 & 81 & 86.8108 & 17.5232 & 1.6632 & 83.5147 & 90.1069 & 37 & 135 \\
\hline & 3 & 68 & 90.7576 & 21.7663 & 1.8945 & 87.0098 & 94.5054 & 9 & 135 \\
\hline & 4 & 57 & 99.0909 & 19.5495 & 4.1680 & 90.4232 & 107.7587 & 45 & 128 \\
\hline & 5 & 54 & 79.9189 & 20.2558 & 3.3300 & 73.1653 & 86.6726 & 40 & 132 \\
\hline & 6 & 56 & 91.5000 & 29.9403 & 8.0019 & 74.2130 & 108.7870 & 21 & 143 \\
\hline & 7 & 42 & 100.1071 & 19.6060 & 3.7052 & 92.5047 & 107.7096 & 59 & 133 \\
\hline & Total & 434 & 87.4895 & 21.2532 & 1.0261 & 85.4727 & 89.5064 & 9 & 143 \\
\hline \multirow{8}{*}{$\begin{array}{l}\text { Fructification } \\
\text { percentage per } \\
\text { inflorescence } \\
\text { (\%) }\end{array}$} & 1 & 76 & 14.8449 & 7.8376 & 0.8501 & 13.1544 & 16.5355 & 2.25 & 40.30 \\
\hline & 2 & 81 & 29.5911 & 8.8956 & 0.8443 & 27.9178 & 31.2643 & 2.70 & 54.93 \\
\hline & 3 & 68 & 13.7125 & 9.0146 & 0.7846 & 12.1603 & 15.2647 & 1.57 & 54.00 \\
\hline & 4 & 57 & 11.4114 & 6.0866 & 1.2977 & 8.7127 & 14.1100 & 2.70 & 24.44 \\
\hline & 5 & 54 & 24.7500 & 11.0672 & 1.8194 & 21.0600 & 28.4400 & 1.94 & 45.57 \\
\hline & 6 & 56 & 17.2143 & 6.1791 & 1.6514 & 13.6466 & 20.7820 & 9.00 & 29.00 \\
\hline & 7 & 42 & 14.7129 & 7.6587 & 1.4474 & 11.7431 & 17.6826 & 5.00 & 36.00 \\
\hline & Total & 434 & 19.0588 & 11.0684 & 0.5344 & 18.0085 & 20.1092 & 1.57 & 54.93 \\
\hline
\end{tabular}


Table 3. Tests of between-subjects effects on flower number and fructification percentage per inflorescence.

\begin{tabular}{|c|c|c|c|c|c|c|c|c|}
\hline \multirow[b]{2}{*}{ Source } & \multicolumn{2}{|c|}{ Type I Sum of Squares } & \multirow[b]{2}{*}{ df } & \multicolumn{2}{|c|}{ Mean Square } & \multicolumn{2}{|c|}{$\mathrm{F}$} & \multirow[b]{2}{*}{ Sig. } \\
\hline & $\begin{array}{l}\text { Flower } \\
\text { number }\end{array}$ & $\begin{array}{l}\text { Fructification } \\
\text { percentage }\end{array}$ & & $\begin{array}{l}\text { Flower } \\
\text { number }\end{array}$ & $\begin{array}{l}\text { Fructification } \\
\text { percentage }\end{array}$ & $\begin{array}{l}\text { Flower } \\
\text { number }\end{array}$ & $\begin{array}{l}\text { Fructification } \\
\text { percentage }\end{array}$ & \\
\hline Corrected Model & $95563.700^{(\mathrm{a})}$ & $33625.699^{(b)}$ & 100 & 955.637 & 336.257 & 3.206 & 5.864 & 0.000 \\
\hline Intercept & 3283743.797 & 155829.605 & 1 & 3283743.797 & 155829.605 & 11017.076 & 2717.516 & 0.000 \\
\hline Population & 17678.427 & 20656.897 & 6 & 2946.404 & 3442.816 & 9.885 & 60.039 & 0.000 \\
\hline Individual & 77885.274 & 12968.802 & 94 & 828.567 & 137.966 & 2.780 & 2.406 & 0.000 \\
\hline Error & 97763.502 & 18808.393 & 333 & 298.059 & 57.343 & & & \\
\hline Total & 3477071.000 & 208263.697 & 434 & & & & & \\
\hline Corrected Total & 193327.203 & 52434.092 & 433 & & & & & \\
\hline
\end{tabular}

${ }^{\mathrm{a}} \mathrm{R}$ Squared $=0.494$ (Adjusted R Squared $\left.=0.340\right) ;{ }^{\mathrm{b}} \mathrm{R}$ Squared $=0.641$ (Adjusted R Squared $\left.=0.532\right)$.

Table 4. Descriptives of seed number per fruit from the seven populations.

\begin{tabular}{|c|c|c|c|c|c|c|c|c|}
\hline \multirow{2}{*}{ Population } & \multirow{2}{*}{$\mathrm{N}$} & \multirow{2}{*}{ Mean } & \multirow{2}{*}{$\begin{array}{c}\text { Std. } \\
\text { Deviation }\end{array}$} & \multirow{2}{*}{ Std. Error } & \multicolumn{2}{|c|}{ 95\% Confidence Interval for Mean } & \multirow{2}{*}{ Minimum } & \multirow{2}{*}{ Maximum } \\
\hline & & & & & Lower Bound & Upper Bound & & \\
\hline 1 & 934 & 25.4366 & 11.6900 & 0.3695 & 24.7115 & 26.1616 & 1 & 60 \\
\hline 2 & 1587 & 37.3830 & 11.7928 & 0.2130 & 36.9654 & 37.8007 & 4 & 81 \\
\hline 3 & 1203 & 29.7468 & 11.3402 & 0.2851 & 29.1876 & 30.3060 & 3 & 64 \\
\hline 4 & 1021 & 30.7009 & 12.4354 & 0.8129 & 29.0992 & 32.3025 & 8 & 64 \\
\hline 5 & 925 & 31.5542 & 12.7687 & 0.4506 & 30.6697 & 32.4387 & 4 & 74 \\
\hline 6 & 906 & 35.3711 & 11.7017 & 0.8401 & 33.7141 & 37.0281 & 5 & 82 \\
\hline 7 & 702 & 34.8195 & 12.6819 & 0.6349 & 33.5714 & 36.0677 & 5 & 72 \\
\hline Total & 7278 & 33.0280 & 12.6339 & 0.1481 & 32.7376 & 33.3183 & 1 & 82 \\
\hline
\end{tabular}

Table 5. Multiple comparisons of seed number per fruit among the seven populations (S-N-K, $\alpha=0.05$ ).

\begin{tabular}{|c|c|c|c|c|c|}
\hline \multirow{2}{*}{ Population } & \multirow{2}{*}{$\mathrm{N}$} & \multicolumn{4}{|c|}{ Subset } \\
\hline & & 1 & 2 & 3 & 4 \\
\hline 1 & 934 & 25.4366 & & & \\
\hline 3 & 1203 & & 29.7933 & & \\
\hline 4 & 1021 & & 30.7009 & & \\
\hline 5 & 925 & & 31.5542 & & \\
\hline 7 & 702 & & & 34.8195 & \\
\hline 6 & 906 & & & 35.3711 & \\
\hline 2 & 1587 & & & & 37.3830 \\
\hline Sig. & & 1.000 & 0.062 & 0.479 & 1.000 \\
\hline
\end{tabular}


ber and fructification percentage per inflorescence $(d f=426, R=-0.261, P=0.000)$; and significant correlations also existed between flower number per inflorescence and seed number per fruit $(d f=426, R=0.132, P=$ $0.006)$, as well as between fructification percentage per inflorescence and seed number per fruit $(d f=426, R=$ $0.278, P=0.000$ ).

By Stepwise, the equation $\left(y=16.251+2.393 x_{3}+0.008 x_{2}\right)$ was the optimal regression model of flower number per inflorescence ( $y$ : flower number per inflorescence, $x_{2}$ : altitude, $x_{3}$ : latitude) (Table 6); the equation $(y=$ $58.209-0.121 x_{1}+0.007 x_{2}-1.770 x_{3}$ ) was the optimal regression model of fructification percentage per inflorescence $\left(y\right.$ : fructification percentage per inflorescence, $x_{1}$ : flower number per inflorescence, $x_{2}$ : altitude, $x_{3}$ : latitude) (Table 7); the equation $\left(y=-35.087+0.010 x_{2}+0.490 x_{4}\right)$ was the optimal regression model of seed number per fruit ( $y$ : seed number per fruit, $x_{2}$ : altitude, $x_{4}$ : longitude) (Table 8).

\subsection{The Influence of Geographical Location on Flower Number and Fructification Percentage per Inflorescence, Seed Number per Fruit}

For the populations located at south of the tropic of cancer ( $\left.23^{\circ} 26^{\prime}\right)$, flower number and fructification percentage per inflorescence, seed number per fruit were $84.57 \pm 20.51$ (range from 21 to 143), $22.08 \pm 11.20$ (range from 1.94 to 54.93 ) \%, $33.87 \pm 12.83$ (range from 1 to 82), respectively; as of the populations at north of the tropic of cancer were $91.57 \pm 21.98$ (range from 9 to 140), $14.10 \pm 9.12$ (range from 1.57 to 54.00 ) $\%, 30.81 \pm$ 11.75 (range from 3 to 72). Greatly significant differences occurred between the two populations of different geographical location, viz. in flower number $(d f=443, F=11.667, P=0.001)$ and fructification percentage per inflorescence $(d f=443, F=62.065, P=0.000)$, and in seed number per fruit $(d f=7274, F=85.656, P=0.000)$.

Table 6. Coefficients ${ }^{(\mathrm{a})}$ for flower number per inflorescence.

\begin{tabular}{|c|c|c|c|c|c|c|}
\hline \multirow{2}{*}{ Model } & & \multicolumn{2}{|c|}{ Unstandardized Coefficients } & \multirow{2}{*}{$\begin{array}{c}\text { Standardized Coefficients } \\
\text { Beta }\end{array}$} & \multirow{2}{*}{$\mathrm{t}$} & \multirow{2}{*}{ Sig. } \\
\hline & & B & Std. Error & & & \\
\hline \multirow[t]{2}{*}{1} & (Constant) & 31.358 & 14.941 & & 2.099 & 0.036 \\
\hline & Latitude & 2.350 & 0.626 & 0.176 & 3.755 & 0.000 \\
\hline \multirow[t]{3}{*}{2} & (Constant) & 16.251 & 16.672 & & 0.975 & 0.330 \\
\hline & Latitude & 2.393 & 0.624 & 0.179 & 3.834 & 0.000 \\
\hline & Altitude & 0.008 & 0.004 & 0.094 & 2.014 & 0.045 \\
\hline
\end{tabular}

${ }^{\mathrm{a}}$ Dependent Variable: flower number per inflorescence.

Table 7. Coefficients ${ }^{(\mathrm{a})}$ for fructification percentage per inflorescence.

\begin{tabular}{|c|c|c|c|c|c|c|}
\hline \multirow{2}{*}{ Model } & & \multicolumn{2}{|c|}{ Unstandardized Coefficients } & \multirow{2}{*}{$\begin{array}{c}\text { Standardized Coefficients } \\
\text { Beta }\end{array}$} & \multirow{2}{*}{$\mathrm{t}$} & \multirow{2}{*}{ Sig. } \\
\hline & & B & Std. Error & & & \\
\hline \multirow[t]{2}{*}{1} & (Constant) & 68.849 & 7.547 & & 9.123 & 0.000 \\
\hline & Latitude & -2.096 & 0.316 & -0.301 & -6.629 & 0.000 \\
\hline \multirow[t]{3}{*}{2} & (Constant) & 72.381 & 7.402 & & 9.779 & 0.000 \\
\hline & Latitude & -1.831 & 0.313 & -0.263 & -5.842 & 0.000 \\
\hline & Flower number per inflorescence & -0.113 & 0.023 & -0.216 & -4.804 & 0.000 \\
\hline \multirow[t]{4}{*}{3} & (Constant) & 58.209 & 8.123 & & 7.166 & 0.000 \\
\hline & Latitude & -1.770 & 0.309 & -0.254 & -5.732 & 0.000 \\
\hline & Flower number per inflorescence & -0.121 & 0.023 & -0.233 & -5.237 & 0.000 \\
\hline & Altitude & 0.007 & 0.002 & 0.172 & 3.939 & 0.000 \\
\hline
\end{tabular}

${ }^{\mathrm{a}}$ Dependent Variable: fructification percentage per inflorescence. 
Table 8. Coefficients ${ }^{(\mathrm{a})}$ for seed number per fruit.

\begin{tabular}{|c|c|c|c|c|c|c|}
\hline \multirow{2}{*}{ Model } & & \multicolumn{2}{|c|}{ Unstandardized Coefficients } & \multirow{2}{*}{$\begin{array}{c}\text { Standardized Coefficients } \\
\text { Beta }\end{array}$} & \multirow{2}{*}{$\mathrm{t}$} & \multirow{2}{*}{ Sig. } \\
\hline & & B & Std. Error & & & \\
\hline \multirow[t]{2}{*}{1} & (Constant) & 16.225 & 1.131 & & 14.339 & 0.000 \\
\hline & Altitude & 0.009 & 0.001 & 0.173 & 14.987 & 0.000 \\
\hline \multirow[t]{3}{*}{2} & (Constant) & -35.087 & 8.089 & & -4.338 & 0.000 \\
\hline & Altitude & 0.010 & 0.001 & 0.189 & 16.052 & 0.000 \\
\hline & Longitude & 0.490 & 0.076 & 0.076 & 6.406 & 0.000 \\
\hline
\end{tabular}

${ }^{a}$ Dependent Variable: seed number per fruit.

\section{Discussion}

\subsection{Correlations among Flower Number per Inflorescence, Fruit and Seed Production in A. tsaoko}

Previous studies on fruiting character of $A$. tsaoko showed that the fruit abortion occurred after initiation because of environmental factors (e.g. humility) [8]. Therefore, in this study, the fructification percentage per inflorescence reflected the plant final reproductive success, which combined both fruit set and fruit abortion. By the optimal regression equations and ANOVA analysis, there was a trade-off between flower number and fructification percentage per inflorescence, and significantly positive correlation between flower number per inflorescence and seed number per fruit. The former relationship was a typical response found in the other plants because of limited reproduction resource [9-11]. An inflorescence was more attractive to pollinator in comparison with a single flower because the integrated flowers were more striking to insects [12,13]. Based on this, the latter relationship implied probably that the inflorescences with numerous flowers easily attracted pollinators for reproduction assurance. The results might be associated with the pollinators (i.e. bees) activity. Because bees didn't visit repeatedly those flowers with low reward, they were likely remembered by their pollinators [14].

Because of limited reproduction resource, a competition among reproductive organs for reproduction assurance was widespread in plants [9]. Therefore, the correlations among flower number per inflorescence, fruit and seed production likely reflected that competition of reproduction resource in A. tsaoko. Results from our study showed the competition for reproductive resource was beneficial to increase flower number and seed production, in contrast, such competition wasn't partial to amplifying fruit number.

\subsection{The Influence of Altitude and Latitude on Flower Number per Inflorescence, Fruit and Seed Production in A. tsaoko}

Results from this study showed that there was a strong effect of both altitude and latitude on the flower number per inflorescence and the fruit production of $A$. tsaoko. When the latitude and/or altitude of those populations were elevated, the flower number per inflorescence increased significantly, on the contrary, the fructification percentage per inflorescence decreased significantly. On contrast to altitude, the influence of latitude on both flower number and fructification percentage per inflorescence was more significant according to the value of coefficients in their optimal regression equations. We suggested that $A$. tsaoko was distributed (or transplanted) from a habitat at lower latitude and/or altitude to a site of higher latitude and/or altitude, the flower number per inflorescence increased, on the contrary, the fructification percentage per inflorescence decreased.

By its optimal regression equation, both altitude and longitude influenced significantly the seed number per fruit. Based on the comparison of their variation (altitude: 1425 - 2070 m vs. longitude: $98^{\circ} 46.501^{\prime}-104^{\circ} 49.333^{\prime}$ ) in the study, we considered that altitude was the main effect on the seed number per fruit, which increased when the altitude of population elevated.

It is known that change of day length is related to latitude, and yearly temperature averages will decrease 
$0.8^{\circ} \mathrm{C}$ as latitude increase $1^{\circ}$ from south to north in the Northern Hemisphere, in addition, temperature would decrease when altitude elevates (i.e. $0.6^{\circ} \mathrm{C} / 100 \mathrm{~m}$ ). The topography of Yunnan shows that the northwest is higher and the southeast lower, so from the east to the west the latitude is rising and the altitude also elevating continually. Therefore, the significant influence of both latitude and altitude on flower number per inflorescence likely reflected that lower temperature and higher temperature difference between day and night would be beneficial to increase the flower number per inflorescence. The fruit and seed production would partly depend on its pollinators. However, cooler temperatures could be a proximate cue for the ultimate factor of low pollinator availability [15]. Therefore, low pollinator activity in habitat where latitude and/or altitude elevated would lead to less fruit and seed production. The tropic of cancer is the boundary between the north temperate zone and the tropic. The populations of $A$. tsaoko growing in south of the tropic of cancer had significantly less flower number per inflorescence, and significantly higher fruit and seed production than the population in north of the tropic of cancer. Such significant differences probably demonstrated that the habitats in south of the tropic of cancer were favorable to the reproduction of $A$. tsaoko, which reproductive costs were lower and harvest was higher. These results would provide beneficial information for further study on the plant about the origin of cultivation, and for selection of cultivated site.

\subsection{Flowering Strategy and Female Fitnesss}

Floral longevity, the length of time a flower remains open and functional, was determined by a balance between female fitness accrual rates (pollen receipt), male fitness accrual rates (pollen dissemination), and the cost of flower maintenance [16-18]. In plant reproductive ecology floral longevity played a central role, it determined plant reproductive assurance and overall fitness [19], because it affected the number of pollinator visits, the amount and quality of pollen received and disseminated, as well as floral display size [20,21]. Floral longevity could ensure successful pollination in habitats where pollinators were few, unpredictable [17,18,20,22]. For example, long floral duration could significantly increase successful pollination and fruit set in Kalmia latifolia [15]. In addition, previous studies demonstrated that plants growing in alpine habitats, which typically had sparse or uncertain pollinators, had longer floral durations than plants at lower elevations with more abundant, predictable pollinators [23-27].

Floral longevity played a central role in the distribution of zingiberaceae from tropics to alpine habitats, in the course the duration of floral life had a tendency to increase for effective enhancement of both female and male fitness. Therefore, based on increasing of floral longevity, ginger was divorced from tropical habitat and distributed toward high elevation habitat [28]. For A. tsaoko, as a flexistylous ginger, the longevity of a single flower was only $1 \mathrm{~d}$, which opened at dawn and withered at dusk. Flexistyly is a unique and "active" floral mechanism to decrease inbreeding and promote outcrossing by changing position of style [29-39]. Therefore, extension of floral longevity for a single $A$. tsaoko flower would not increase outcrossing.

Our study in Baoshan population suggested that floral longevity of $A$. tsaoko was only $1 \mathrm{~d}$, and the flowers in inflorescence opened in proper order every day, i.e. 1 - 6 flowers per $1 \mathrm{~d}$ for the most inflorescences and mean 3 - 4 flowers per $1 \mathrm{~d}$ [40]. Cui et al. suggested that floral longevity of A. tsaoko in Yuanjiang population was only $1 \mathrm{~d}$, and 3 - 5 flowers from an inflorescence opened every day [8]. Based on this, the inflorescence with more flowers had longer anthesis, meaning that the floral longevity was prolonged at the inflorescence level. In addition, an inflorescence was more attractive to pollinator than a single flower [12,13]. Therefore, increasing flower number per inflorescence may be a strategy to having greater attraction to pollinators for both female and male reproductive success. The strategy would promote the plant to distribute into those habitats with higher elevation, where its pollinator was unpredictable or sparse.

By the ANOVA analysis, both plant-intrinsic and environmental factors influenced significantly the flower number per inflorescence, fruit and seed production $(P=0.000<0.01)$. For the seed number per fruit, effect of the former was stronger than the latter. On the contrary, both flower number and fructification percentage per inflorescence were influenced by environmental factors more than plant-intrinsic factors. Therefore, the seed number per fruit possibly reflected that the certain plant-intrinsic trait, which might demonstrate that the plant individuals differed in reproductive resource status conditions. Such as different rate of nectar secretion among the plant individuals, and those flowers with higher rewards might receive more visits from pollinators (unpublished data), and possibly more seed number per fruit. A further study on the seed production will provide further insight into the fitness and the ecological adaptation of the plant. 


\section{Acknowledgements}

The research was supported by a grant from Science and Technology Projects of Yunnan Province (2009CD078) and the Science Foundation of Yunnan Education Bureau (2010Z097).

\section{References}

[1] Chinese Pharmacopoeia Commission (2010) Pharmacopoeia of the People's Republic of China (Vol. 1). Chinese Medicine Science and Technology Press, Beijing, 222-223.

[2] Wu, Z.Y. and Raven, P.H. (2000) Flora of China (Vol. 24). (Flagellariaceae through Marantaceae). Science Press, Beijing, and Missouri Botanical Garden Press, St. Louis.

[3] Pendleton R.L., Freeman D.C., Mctrthur E.D. and Sanderson S.C. (2000) Gender Specialization in Heterodichogamous Grayia brandegei (Chenopodiaceae): Evidence for an Alternative Pathway to Dioecy. American Journal of Botany, 87, 508-516. http://dx.doi.org/10.2307/2656594

[4] Pannell J.R. and Verdu M. (2006) The Evolution of Gender Specialization from Dimorphic Hermaphroditism: Paths from Heterodichogamy to Gynodioecy and Androdioecy. Evolution, 60, 660-673. http://dx.doi.org/10.1554/05-481.1

[5] Abdala-Roberts, L., Parra-Tabla, V. and Navarro, J. (2007) Is Floral Longevity Influenced by Reproductive Costs and Pollination Success in Cohniella ascendens (Orchidaceae)? Annals of Botany, 100, 1367-1371. http://dx.doi.org/10.1093/aob/mcm219

[6] Sun, S., Cao, G.-X., Luo, Y.-J. and Li, Q.-J. (2010) Maintenance and Functional Gender Specialization of Flexistyly. Chinese Journal of Plant Ecology, 34, 827-838.

[7] Wu, Z.Y. and Zhu, Y.C. (1987) Yunnan Vegetation. Science Press, Beijing, 31-32.

[8] Cui, X.L., Wei, R.C. and Huang, R.F. (1996) Biological Characters of Flowering and Fruiting Habit in Amomum tsaoko. Southwest China Journal Agriculture Science, 9, 109-113.

[9] Lloyd, D.G. (1987) Selection of Offspring Size at Independence and Other-Size-verus Number Strategies. American Naturalist, 129, 800-817. http://dx.doi.org/10.1086/284676

[10] Thomson, J.D. (1989) Deployment of Ovules and Pollen among Flowers within Inflorescences. Evolutionary Trends in Plants, 3, 65-68.

[11] Campbell, D.R. (2000) Experimental Tests of Sex-Allocation Theory in Plants. Trends in Ecology and Evolution, 15, 227-232. http://dx.doi.org/10.1016/S0169-5347(00)01872-3

[12] Mu, I.I., Igan, G.A. and Kevan, P.G. (1973) Color, brightness and Other Floral Characteristics Attracting Insects to the Blossoms of some Canadian Weed. Canadian Journal of Botany, 51, 1939-1952. http://dx.doi.org/10.1139/b73-248

[13] Zhou, S.L., Pan, K.Y. and Hong, D.Y. (1996) Comparative Study on Pollination Biology of Mosla hangthouensis and M. chinense. Acta Botanica Sinica, 38, 530-540.

[14] Chen, H.Z. and Yang, Y. (1989) Behavior of Bee and Environment. Journal of Bee, 5, 39-40.

[15] Rathcke, B.J. (2003) Floral Longevity and Reproductive Assurance: Seasonal Patterns and an Experimental Test with kalmia latifolia (Ericaceae). American Journal of Botany, 90, 1328-1332. http://dx.doi.org/10.3732/ajb.90.9.1328

[16] Charnov, E.L. (1996) Optimal Flower Lifetimes. Evolutionary Ecology, 10, 245-248. http://dx.doi.org/10.1007/BF01237682

[17] Ashman, T.L. and Schoen, D. J. (1994) How Long Should Flowers Live? Nature, 371, 788-791. http://dx.doi.org/10.1038/371788a0

[18] Ashman, T.L. and Schoen, D.J. (1996) Floral Longevity: Fitness Consequences and Resource Costs. In: Lloyd, D.G. and Barrett, S.C.H., Eds., Floral Biology: Studies on Floral Evolution in Animal-Pollinated Plants, Chapman and Hall, New York, 112-138. http://dx.doi.org/10.1007/978-1-4613-1165-2_5

[19] Rathcke, B.J. (2003) Floral Longevity and Reproductive Assurance: Seasonal Patterns and an Experimental Test with Kalmia latifolia (Ericaceae). American Journal of Botany, 90, 1328-1332. http://dx.doi.org/10.3732/ajb.90.9.1328

[20] Primack, R.B. (1985) Longevity of Individual Flowers. Annual Review of Ecology and Systematics, 16, 15-37. http://dx.doi.org/10.1146/annurev.es.16.110185.000311

[21] Harder, L.D. and Johnson, S.D. (2005) Adaptive Plasticity of Floral Display Size in Animal-Pollinated Plants. Proceedings of the Royal Society, Series B, 272, 2651-2657. http://dx.doi.org/10.1098/rspb.2005.3268

[22] Khadari, B., Gibernau, M., Anstett, M.C., Jellberg, F.K. and Hos-Saert-Mckey, M. (1995) When Figs Wait for Pollinators: the Length of Fig Receptivity. American Journal of Botany, 82, 992-999. http://dx.doi.org/10.2307/2446228

[23] Arroyo, M.T.K., Armesto, J.J. and Villagran, C. (1981) Plant Phenological Patterns in the High Andean Cordillera of 
Central Chile. Journal of Ecology, 69, 205-223. http://dx.doi.org/10.2307/2259826

[24] Stratton, D.A. (1989) Longevity of Individual Flowers in a Costa Rican Cloud Forest: Ecological Correlates and Phylogenetic Constraints. Biotropica, 21, 308-318. http://dx.doi.org/10.2307/2388281

[25] Bingham, R.A. and Orthner, A.R. (1998) Efficient Pollination of Alpine Plants. Nature, 391, 238-239. http://dx.doi.org/10.1038/34564

[26] Blionis, G.J. and Vokou, D. (2001) Pollination Ecology of Campanula Species on Mt Olympos, Greece. Ecography, 24, 287-297.

[27] Blionis, G.J., Halley, J.M. and Vokou, D. (2001) Flowering Phenology of Campanula on Mt Olympos, Greece. Ecography, 24, 696-706. http://dx.doi.org/10.1034/j.1600-0587.2001.240608.X

[28] Gao, J.-Y., Yang, Z.-H. and Li, Q.-J. (2009) Effect of Floral Longevity on Male and Female Fitness in Hedychium villosum var. villosum. Chinese Journal of Plant Ecology, 33, 89-96.

[29] Cui, X.L., Wei, R.C. and Huang, R.F. (1995) A Preliminary Study on the Genetic System of Amomum tsaoko. Journal Yunnan University, 17, 290-297.

[30] Cui, X.L., Wei, R.C. and Huang, R.F. (1995) Study on the Artificial Population Structure of Amomum tsaoko. Southwest China Journal Agriculture Science, 8, 114-118.

[31] Renner, S.S. (2001) Heterodichogamy, How Common Is It? Trends in Ecology and Evolution, 16, 595-597. http://dx.doi.org/10.1016/S0169-5347(01)02280-7

[32] Li, Q.J., Xu, Z.F., Kress, W.J., Xia, Y.M., Zhang, L., Deng, X.B., Gao, J.Y. and Bai, Z.L. (2001) Flexible Style That Encourage Outcrossing. Nature, 410, 432. http://dx.doi.org/10.1038/35068635

[33] Li, Q.J., Xu, Z.F., Kress, W.J., Xia, Y.M., Zhang, L., Deng, X.B. and Gao, J.Y. (2001) Study on the Flexistyly Pollination Mechanism in Alpinia Plants (Zingiberaceae). Acta Botany Sinica, 43, 346-369.

[34] Li, Q.J., Kress, W.J., Xu, Z. F., Xia, Y.M., Zhang, L., Deng, X.B. and Gao, J.Y. (2002) Mating System and Stigmatic Behaviour during Flowering of Alpinia kwangsiensis (Zingiberaceae). Plant Systematics and Evolution, 232, 123-132. http://dx.doi.org/10.1007/s006060200031

[35] Zhang, L. and Li, Q.J. (2002) Flexistyly and Its Evolutionary Ecological Significance. Acta Phytoecologica Sinica, 26, 385-390.

[36] Barrett, S.C.H. (2002) The Evolution of Plant Sexual Diversity. Natural Reviews Genetics, 3, 274-284. http://dx.doi.org/10.1038/nrg776

[37] Wang, Y.Q., Zhang, D.X. and Chen, Z.Y. (2005) Pollination Biology of Alpinia hainanensis (Zingiberaceae). Acta Phytotaxonomica Sinica, 43, 37-49. http://dx.doi.org/10.1360/aps040039

[38] Wang, Y.Q., Zhang, D.X. and Chen, Z.Y. (2005) A Preliminary Study of the Pollination Biology of Alpinia oxyphylla (Zingiberaceae). Acta Phytoecologica Sinica, 29, 599-609.

[39] Takano, A., Gisil, J., Yusoff, M. and Tachi, T. (2005) Floral and Pollinator Behaviour of Flexistylous Bornran Ginger, Alpinia nieuwenhuizii (Zingiberaceae). Plant Systematics and Evolution, 252, 167-173. http://dx.doi.org/10.1007/s00606-004-0258-4

[40] Yang, Y.-W., Liu, X.-L., You, C. and Qian, Z.-G. (2013) Study on the Development and Flowering of Inflorescence in Amomum tsaoko (Zingiberaceae). Lishizhen Medicine and Materia Medica Research, 243, 740-742. 